SEMISYNTHETIC $\beta$-LACTAM ANTIBIOTICS

III. EFFECT ON ANTIBACTERIAL ACTIVITY AND COMTSUSCEPTIBILITY OF CHLORINE-INTRODUCTION INTO THE CATECHOL NUCLEUS OF 6-[(R)-2-[3-(3,4-DIHYDROXYBENZOYL)-3(3-HYDROXYPROPYL)-1-UREIDO]-2PHENYLACETAMIDO]PENICILLANIC ACID

\author{
Nobuhiro Ohi, Bunya Aoki, Toshio Kuroki, Masahiko Matsumoto,
} KaNa KoJima and Toshiyuki NeHashi

New Drug Research Laboratories, Chugai Pharmaceutical Co., Ltd., 3-41-8 Takada, Toshima-ku, Tokyo 171, Japan

(Received for publication July 11, 1986)

\begin{abstract}
The resistance of 6-[(R)-2-[3-(3,4-dihydroxybenzoyl)-3-(3-hydroxypropyl)-1-ureido]-2phenylacetamidolpenicillanic acid (1a) to metabolism by catechol- $O$-methyl-transferase (COMT) was increased by introduction of the chlorine atom into the catechol moiety. Penicillins (1b $\sim \mathbf{1 d})$ having one or two chlorine atoms at the positions adjacent to the hydroxyl group were found to have greater stability to COMT. This resulted in greater efficiency in vivo in experimental Pseudomonas aeruginosa and Escherichia coli infections. In vitro activities were essentially unchanged.
\end{abstract}

A recent target in chemotherapy has been the treatment of opportunistic infections caused by Gram-negative bacteria such as Pseudomonas aeruginosa and Serratia marcescens.

In our previous publications, ${ }^{1,2)}$ we reported that the new ureidopenicillin derivatives with the catechol moiety have strong activity in vitro against Gram-negative bacteria including $P$. aeruginosa. Of these, 6-[(R)-2-[3-(3,4-dihydroxybenzoyl)-3-(3-hydroxypropyl)-1-ureido]-2-phenylacetamido]penicillanic acid (1a, AO-1100) in particular showed potent in vivo as well as in vitro activity against $P$. aeruginosa.

The catechol moiety is metabolized by catechol-O-methyl-transferase (COMT) with rapid conversion of the hydroxyl group to a methoxyl group. Penicillin (AO-1100, 1a) also is presumed to lose its antibacterial activity through $O$-methylation. Therefore, we continued drug-design to improve the stability of 1a to COMT.

In the present paper, we describe the influence of chlorine substitution in the catechol benzene nucleus on antibacterial activity and COMT-susceptibility.

\title{
Chemistry
}

The novel penicillins (1b $\sim \mathbf{1 d}$ ) are obtained from the 3,4-dihydroxybenzamides (11), trichloromethyl chloroformate (TCF) and ampicillin (ABPC) as reported previously. ${ }^{1,2)}$ Introduction of the chlorine atom into the position adjacent to the hydroxyl group in the amides (11) is accomplished as outlined in Scheme 1. Chlorine atoms were introduced to the ortho-position of the hydroxyl group by the reaction of benzoic acids $(2 \sim 4)$ with sulfuryl chloride $\left(\mathrm{SO}_{2} \mathrm{Cl}_{2}\right){ }^{3}$ ) For example, 3,4-dihydroxybenzoic acid (2) was converted into 2,5-dichloro-3,4-dihydroxybenzoic acid (5) by reaction with $\mathrm{SO}_{2} \mathrm{Cl}_{2}$ in 
Scheme 1.<smiles>[R17]C(=O)c1cc([X])c(O)c(O)c1[Y]</smiles>

1

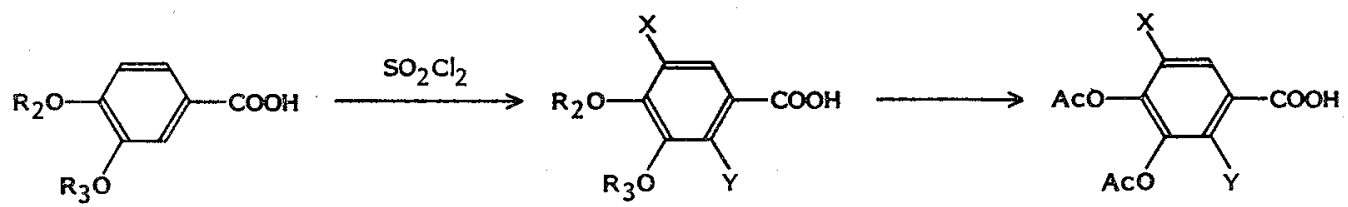

$\begin{array}{ll}2 \mathrm{R}_{2}=\mathrm{R}_{3}=\mathrm{H} & \mathbf{5} \mathrm{R}_{2}=\mathrm{R}_{3}=\mathrm{H}, \mathrm{X}=\mathrm{Y}=\mathrm{Cl} \\ \mathbf{3} \mathrm{R}_{2}=\mathrm{H}, \mathrm{R}_{3}=\mathrm{CH}_{3} & 6 \mathrm{R}_{2}=\mathrm{H}, \mathrm{R}_{3}=\mathrm{CH}_{3}, \mathrm{X}=\mathrm{Cl}, \mathrm{Y}=\mathrm{H} \\ \text { 4 } \mathrm{R}_{2}=\mathrm{CH}_{3}, \mathrm{R}_{3}=\mathrm{H} & \mathbf{T} \mathrm{R}_{2}=\mathrm{CH}_{3}, \mathrm{R}_{3}=\mathrm{H}, \mathrm{X}=\mathrm{H}, \mathrm{Y}=\mathrm{Cl} \\ & 8 \mathrm{R}_{2}=\mathrm{R}_{3}=\mathrm{H}, \mathrm{X}=\mathrm{Cl}, \mathrm{Y}=\mathrm{H} \\ & 9 \mathrm{R}_{2}=\mathrm{R}_{3}=\mathrm{H}, \mathrm{X}=\mathrm{H}, \mathrm{Y}=\mathrm{Cl}\end{array}$

10

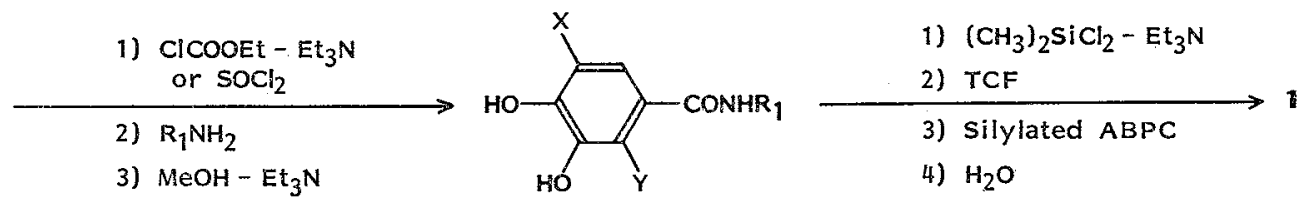

11

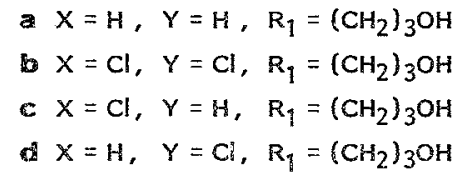

$X=H, Y=C l, R_{1}=\left(\mathrm{CH}_{2}\right)_{3} \mathrm{OH}$

acetic acid. Similarly, 3-chloro-4-hydroxy-5-methoxybenzoic acid (6) and 2-chloro-3-hydroxy-4methoxybenzoic acid (7) were obtained from vanillic acid (3) and isovanillic acid (4), respectively. Demethylation of the methoxyl group was carried out by treatment with $\mathrm{AlCl}_{8}$ in benzene ${ }^{4}$ to yield dihydroxybenzoic acids $(\mathbf{8}, 9)$, which in turn were converted into the amides (11) via diacetoxy derivatives (10).

\section{Biological Activity}

The antibacterial activity in vitro of penicillins $(\mathbf{1 a} \sim \mathbf{1 d})$ is given in Table 1. Against some strains of Bacillus subtilis, Staphylococcus aureus and Micrococcus luteus, AO-1100 (1a) was relatively the most potent. But all four penicillins had similar activity against the other strains used in this experiment. 
Table 1. Antibacterial activity of penicillins (1).

\begin{tabular}{|c|c|c|c|c|}
\hline \multirow{2}{*}{ Test organism } & \multicolumn{4}{|c|}{$\operatorname{MIC}(\mu \mathrm{g} / \mathrm{ml})^{2}$} \\
\hline & $(\mathrm{X}=\stackrel{\mathbf{l a}}{\mathrm{Y}}=\mathrm{H})$ & $(\mathrm{X}=\stackrel{\mathbf{1 b}}{\mathrm{Y}}=\mathrm{Cl})$ & $(\mathrm{X}=\mathrm{Cl}, \mathrm{Y}=\mathrm{H})$ & $(\mathrm{X}=\mathrm{H}, \mathrm{Yd}=\mathrm{Cl})$ \\
\hline Bacillus subtilis ATCC 6633 & 0.78 & 3.12 & 1.56 & 1.56 \\
\hline Staphylococcus aureus 209P & 0.78 & 3.12 & 3.12 & 1.56 \\
\hline Micrococcus luteus B & $\leqq 0.1$ & 0.78 & 0.39 & 0.39 \\
\hline Escherichia coli $\mathrm{NIHJ}$ & 0.78 & 1.56 & 0.39 & 0.78 \\
\hline E. coli 41 & 0.78 & 0.2 & 0.78 & 0.39 \\
\hline Shigella flexneri $2 \mathrm{~b}$ & $\leqq 0.1$ & $\leqq 0.1$ & $\leqq 0.1$ & $\leqq 0.1$ \\
\hline Salmonella paratyphimurium A & $\leqq 0.1$ & $\leqq 0.1$ & $\leqq 0.1$ & $\leqq 0.1$ \\
\hline Klebsiella pneumoniae $15 \mathrm{C}$ & 0.2 & $\leqq 0.1$ & $\leqq 0.1$ & $\leqq 0.1$ \\
\hline K. pneumoniae $3 \mathrm{k} 25$ & 0.39 & $\leqq 0.1$ & 0.2 & 0.2 \\
\hline Proteus mirabilis $9^{\prime}$ & 0.78 & 0.2 & 0.2 & 0.39 \\
\hline Pseudomonas aeruginosa $\mathrm{J}-166$ & 1.56 & 0.78 & 0.78 & 3.12 \\
\hline$P$. aeruginosa $\mathrm{J}-272$ & 0.39 & 0.39 & 0.78 & 1.56 \\
\hline$P$. aeruginosa $\mathrm{J}-276$ & 0.2 & 0.2 & 0.39 & 0.78 \\
\hline$P$. aeruginosa $\mathrm{KAN}-2$ & 0.2 & $\leqq 0.1$ & 0.39 & 0.39 \\
\hline$P$. aeruginosa GNB-75 & $\leqq 0.1$ & $\leqq 0.1$ & $\leqq 0.1$ & $\leqq 0.1$ \\
\hline P. aeruginosa GNB-75 M-57740 & $\leqq 0.1$ & $\leqq 0.1$ & $\leqq 0.1$ & $\leqq 0.1$ \\
\hline
\end{tabular}

a The MICs were determined by a standard dilution method in Mueller-Hinton agar (Difco). Inoculum size: $10^{8}$ cells $/ \mathrm{ml}$.

Table 2. Susceptibility of penicillins (1) to COMT.

\begin{tabular}{ccccc}
\hline \multirow{2}{*}{ Compound } & \multicolumn{3}{c}{ Concentration $(\mu \mathrm{M})^{\mathrm{a}}$} & $\mathrm{C}^{\text {Remaining }} \begin{array}{c}\mathrm{C}_{\text {activity }} \\
(\mathrm{S})^{\mathrm{c}}\end{array}$ \\
\cline { 2 - 5 } & $\mathrm{C}_{\mathrm{o}}$ & $\mathrm{C}_{\mathrm{t}}$ & $\mathrm{R}$ & 65.9 \\
1a & $29.3 \pm 3.1^{\mathrm{b}}$ & $20.7 \pm 2.3$ & $10.7 \pm 4.5$ & 94.7 \\
1b & $22.7 \pm 5.0$ & $21.4 \pm 3.9$ & $20.2 \pm 3.2$ & 98.6 \\
1c & $20.9 \pm 1.8$ & $18.6 \pm 5.6$ & $18.3 \pm 1.5$ & 82.9 \\
\hline
\end{tabular}

a See Experimental section.

b Number represent the mean \pm standard deviation from 3 reactants.

c Calculated as follows: $\mathrm{S}=\left(\mathrm{R}+\mathrm{C}_{0}-\mathrm{C}_{\mathrm{t}}\right) / \mathrm{C}_{\mathrm{o}} \times 100$.

Table 2 shows the susceptibility of the four penicillins to COMT. As anticipated, penicillins $(\mathbf{1 b} \sim 1 \mathrm{~d})$ carrying one or two chlorine atoms in the position adjacent to the hydroxyl group were significantly more stable than $\mathbf{1 a}$ to COMT. The ranking of their stability was as follows, $\mathbf{1 b} \div \mathbf{1 c}>\mathbf{1 d}$, suggesting that the introduction of chlorine atom in the 5-position in the benzene ring produce greater stability.

In vivo activities of the penicillins (1a $\sim 1$ d) were compared on the bases of $\mathrm{ED}_{50}$ values obtained using mice infected intraperitoneally with $P$. aeruginosa J-272, $P$. aeruginosa $\mathrm{J}-276$ and Escherichia coli 41 . The results are summarized in Table 3. Furthermore, we examined the protein binding rates of the penicillins $(\mathbf{1 a} \sim \mathbf{1 d})$ to obtain the results given in Table 4. The penicillins $(\mathbf{1 b} \sim \mathbf{1 d})$ with one 
Table 3. Protective effects of penicillins (1) on various experimental infections in mice.

\begin{tabular}{|c|c|c|c|}
\hline Challenge organism & $\begin{array}{c}\text { Infective } \\
\text { inoculum } \\
\text { (cfu/mouse) }\end{array}$ & Compound & $\mathrm{ED}_{50}(\mathrm{mg} / \mathrm{mouse})$ \\
\hline \multirow[t]{4}{*}{$P_{\text {seudomonas aeruginosa } \mathrm{J}-272 * *}$} & $5 \times 10^{4}$ & $1 \mathbf{a}$ & $0.90(0.38 \sim 2.1)$ \\
\hline & & $\mathbf{1 b}$ & nt \\
\hline & & lc & $0.30(0.13 \sim 0.71)$ \\
\hline & & 1d & $0.15(0.078 \sim 0.31)$ \\
\hline \multirow[t]{4}{*}{$P$. aeruginosa $\mathrm{J}-276^{*}$} & $4 \times 10^{4}$ & 1a & $1.14(0.66 \sim 1.96)$ \\
\hline & & $\mathbf{1 b}$ & $0.28(0.17 \sim 0.49)$ \\
\hline & & 1c & $0.86(0.38 \sim 1.86)$ \\
\hline & & 1d & $0.86(0.27 \sim 2.73)$ \\
\hline \multirow[t]{4}{*}{ Escherichia coli $41^{* *}$} & $1 \times 10^{4}$ & $\mathbf{1 a}$ & $0.072(0.047 \sim 0.11)$ \\
\hline & & $\mathbf{1 b}$ & $0.014(0.009 \sim 0.021)$ \\
\hline & & 1c & $0.030(0.018 \sim 0.051)$ \\
\hline & & 1d & $0.030(0.018 \sim 0.051)$ \\
\hline
\end{tabular}

Drugs were administered subcutaneously 1 hour $\left(^{*}\right)$ or 1 and 3 hour(s) (**) after infection.

nt: Not tested.

Table 4. Protein binding rates of penicillins (1).

\begin{tabular}{cc}
\hline Compound & Binding rate $(\%)$ \\
\hline $\mathbf{1 a}$ & 59 \\
$\mathbf{1 b}$ & 93 \\
$\mathbf{1 c}$ & 88 \\
$\mathbf{1 d}$ & 81 \\
\hline
\end{tabular}

Drug conc: $25 \mu \mathrm{g} / \mathrm{ml}$.

Incubation: $37^{\circ} \mathrm{C}, 1$ hour.

Strain: Pseudomonas aeruginosa J-276. or two chlorine atoms were found to have higher binding rates than 1a. The therapeutic efficacies of the penicillins (1c, 1d) were more potent than that of 1a on $P$. aeruginosa J-272 infection. On $P$. aeruginosa $\mathrm{J}-276$ and $E$. coli 41 infections, 1 b was the most potent while the two penicillins with one chlorine atom appeared slightly more potent as compared with $\mathbf{1 a}$.

We conclude that the instability to COMT

of penicillins $(\mathbf{1 b} \sim \mathbf{1 d})$ were improved by introducing one or two chlorine atoms and the improvement was reflected partially by the in vivo activity although the potencies were not always consistent with the ranking of the stability to COMT.

\section{Experimental}

All melting points are uncorrected. IR spectra were recorded on a Hitachi EPI-G3 spectrophotometer. ${ }^{1} \mathrm{H}$ NMR spectra were recorded on a Hitachi R-20A spectrometer using TMS as an internal standard; all chemical shifts are reported in $\delta$ values.

Determination of In Vitro Antibacterial Activity

MICs were determined by the agar dilution method using Mueller-Hinton agar (Difco) after incubation at $37^{\circ} \mathrm{C}$ for 20 hours and an inoculum size of about $10^{\circ} \mathrm{cfu} / \mathrm{ml}$.

Therapeutic Activity in Experimental Infections in Mice

Male $d d \mathrm{Y} /$ slc mice, $5 \sim 6$ week-old, were used. Bacteria, cultured on heart infusion agar plates overnight, were suspended in $5 \%$ gastric mucin and injected intraperitoneally into mice. The test compounds were serially diluted 3 -fold with saline and $0.2 \mathrm{ml}$ of each dilution was administered subcutaneously to mice at 1 hour or 1 and 3 hour(s) after the infection. Each experimental group consisted of 5 mice. The dose in $\mathrm{mg} /$ mouse required to protect $50 \%$ of the mice from death $\left(\mathrm{ED}_{50}\right)$ for 7 days was calculated by the BEHRENS-KARBER method. ${ }^{5}$

Enzymatic $O$-Methylation by Catechol- $O$-methyl-transferase (COMT) System ${ }^{6}$ )

The enzyme solution was prepared with the following components: Tris(hydroxymethyl)amino- 
methane buffer (pH 7.9, $50 \mu \mathrm{mol}) ; \mathrm{MgCl}_{2}(10 \mu \mathrm{mol}) ; S$-adenosylmethionine sulfate $(0.2 \mu \mathrm{mol})$; COMT (50 units); dithiothreitol $(1 \mu \mathrm{mol})$; and water. The final volume was adjusted to $0.9 \mathrm{ml}$. The reaction was started by adding a test compound $(0.1 \mu \mathrm{mol})$ in water $(0.1 \mathrm{ml})$ to the enzyme solution and the mixture was incubated for 30 minutes at $37^{\circ} \mathrm{C}$. The reaction was terminated by the addition of acetone $(1.0 \mathrm{ml})$ and the mixture was centrifuged at $1,500 \times g$ for 10 minutes. An aliquot $(1.0 \mathrm{ml})$ of the supernatant was diluted with phosphate buffer $(\mathrm{pH} 6.5,100 \mathrm{~mm})(3.0 \mathrm{ml})$ and examined for the amount of the compound remaining by an usual agar diffusion technique (paper disk method using $P$. aeruginosa GNB-139 as the test strain). Susceptibility of the compound to enzymatic $O$ methylation was calculated as relative residual activity (S).

$$
\mathrm{S}=\left(\mathrm{R}+\mathrm{C}_{\mathrm{o}}-\mathrm{C}_{\mathrm{t}}\right) / \mathrm{C}_{\mathrm{o}} \times 100
$$

$\mathrm{R}$ represents the amount of the remaining compound after the reaction, $\mathrm{C}_{\mathrm{o}}$; the amount of the compound in the reaction mixture sustained in ice bath, and $\mathrm{C}_{t}$; the amount of the compound in the reaction mixture incubated at $37^{\circ} \mathrm{C}$ without $S$-adenosylmethionine.

\section{Protein Binding Rate ${ }^{7}$}

A mixture of a test compound $(25 \mu \mathrm{g})$ and $4 \%$ bovine serum albumin (Armour Pharm. Co., Ltd.) ( $1 \mathrm{ml}$ ) was incubated at $37^{\circ} \mathrm{C}$ for 60 minutes and passed through an Amicon ultrafilter (CF25, Tokyo). The residual activity (A) was determined by the bioassay against $P$. aeruginosa J-276. The protein binding rate $(\mathrm{P})$ was calculated as follows;

$$
\mathrm{P}(\%)=(1-\mathrm{A} / 25) \times 100
$$

\section{2,5-Dichloro-3,4-dihydroxybenzoic Acid (5)}

A mixture of 3,4-dihydroxybenzoic acid (2) $(50.0 \mathrm{~g})$ and sulfuryl chloride $(105.1 \mathrm{~g})$ in $\mathrm{AcOH}$ $(200 \mathrm{ml})$ was stirred at $45 \sim 50^{\circ} \mathrm{C}$ for 9 hours. After cooling, the crystalline precipitates were collected by filtration and recrystallized from EtOAc - $n$-hexane to afford $5(37.8 \mathrm{~g})$ as colorless crystals: MP $230 \sim 231^{\circ} \mathrm{C}$; IR $(\mathrm{KBr}) \mathrm{cm}^{-1} 3490,1690,1660,1585$.

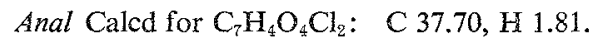

Compounds 6 and 7 were similarly prepared by the method as described for 5 .

6: $\mathrm{MP} 250 \sim 251^{\circ} \mathrm{C}$; IR $(\mathrm{KBr}) \mathrm{cm}^{-1} 3400,1670,1590 ;{ }^{3} \mathrm{H}$ NMR (DMSO- $\left.d_{6}\right) \delta 3.87(3 \mathrm{H}, \mathrm{s}), 7.42$, $7.53(2 \mathrm{H}, \mathrm{ABq}, J=1 \mathrm{~Hz})$.
Anal Calcd for $\mathrm{C}_{8} \mathrm{H}_{7} \mathrm{O}_{4} \mathrm{Cl}$ :
C 47.43, H 3.48 Found:

C 47.89, H 3.58 .

7: MP 233 234 ${ }^{\circ} \mathrm{C}$; IR (KBr) cm ${ }^{-1} 3450,3390,1670,1595 ;{ }^{1} \mathrm{H}$ NMR (DMSO-d $\left.d_{6}\right) \delta 3.87(3 \mathrm{H}$, s), $6.95,7.35(2 \mathrm{H}, \mathrm{AEq}, J=8 \mathrm{~Hz})$.

Anal Calcd for $\mathrm{C}_{8} \mathrm{H}_{7} \mathrm{O}_{4} \mathrm{Cl}:$ C $47.43, \mathrm{H} 3.48$.

$$
\text { Found: } \quad \mathrm{C} 47.49, \mathrm{H} 3.37 \text {. }
$$

3-Chloro-4,5-dihydroxybenzoic Acid (8)

A mixture of 3-chloro-4-hydroxy-5-methoxybenzoic acid (6) $(5.0 \mathrm{~g})$ and anhydrous aluminum chloride $(32.9 \mathrm{~g})$ in dry benzene $(400 \mathrm{ml})$ was heated at reflux for 4 hours. The reaction mixture was cooled with ice bath and cautiously treated with hydrochloric acid $(150 \mathrm{ml})$ and water $(100 \mathrm{ml})$. Extraction of the aqueous mixture with ether was preceded by separating and discarding the benzene solution. The solvent was removed from the ether extract and the residue thus obtained was crystallized from water to give $8(3.8 \mathrm{~g})$ as colorless crystals: MP $235 \sim 236^{\circ} \mathrm{C}$; IR (KBr) $\mathrm{cm}^{-1} 3440,1680$, 1600.

$$
\begin{array}{ll}
\text { Anal Calcd for } \mathrm{C}_{7} \mathrm{H}_{5} \mathrm{O}_{4} \mathrm{Cl} \text { : } & \mathrm{C} 44.55, \mathrm{H} 2.67 . \\
\text { Found: } & \mathrm{C} 44.70, \mathrm{H} 2.74 .
\end{array}
$$

Compound 9 was also prepared by the method as described for 8 .

9: $\mathrm{MP} 227 \sim 228^{\circ} \mathrm{C}$; IR $(\mathrm{KBr}) \mathrm{cm}^{-1} 3470,1690,1595$.

Anal Calcd for $\mathrm{C}_{7} \mathrm{H}_{5} \mathrm{O}_{4} \mathrm{Cl}$ : C $44.55, \mathrm{H} 2.67$.

$$
\text { Found: } \quad \mathrm{C} 44.71, \mathrm{H} 2.51 \text {. }
$$

2,5-Dichloro-3,4-diacetoxybenzoic Acid (10b)

Compound $5(20.0 \mathrm{~g})$ was suspended in the mixture of acetic anhydride $(50 \mathrm{ml})$ and acetic acid 
$(50 \mathrm{ml})$, and catalytic amount of pyridine was added to the stirred suspension. After stirring overnight, the reaction mixture was poured into ice-water and extracted with EtOAc. The organic layer was separated, dried over $\mathrm{MgSO}_{4}$ and evaporated in vacuo. The residue was crystallized from EtOAc $n$-hexane to give 10b $(15.0 \mathrm{~g}):$ MP $169 \sim 170^{\circ} \mathrm{C}(\mathrm{dec})$; IR $(\mathrm{KBr}) \mathrm{cm}^{-1} 1785,1700 ;{ }^{1} \mathrm{H}$ NMR (DMSO$\left.d_{6}\right) \delta 2.41(6 \mathrm{H}, \mathrm{s}), 8.02(1 \mathrm{H}, \mathrm{s})$.

Anal Caled for $\mathrm{C}_{11} \mathrm{H}_{8} \mathrm{O}_{6} \mathrm{Cl}_{2}: \quad \mathrm{C} 43.02, \mathrm{H} 2.63$. Found: $\quad \mathrm{C} 43.23, \mathrm{H} 2.69$.

10c: MP $178^{\circ} \mathrm{C}(\mathrm{dec})$; IR $(\mathrm{KBr}) \mathrm{cm}^{-1} 1770,1690 ;{ }^{1} \mathrm{H}$ NMR (DMSO-d $\left.\theta_{0}\right) \delta 2.31(3 \mathrm{H}, \mathrm{s}), 2.40$ $(3 \mathrm{H}, \mathrm{s}), 7.90,8.03(2 \mathrm{H}, \mathrm{ABq}, J=1 \mathrm{~Hz})$.

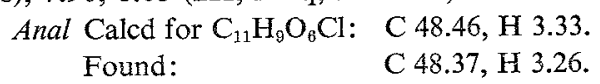

10d: MP $169 \sim 170^{\circ} \mathrm{C}(\mathrm{dec})$; IR (KBr) $\mathrm{cm}^{-1} 1775,1690 ;{ }^{1} \mathrm{H}$ NMR (DMSO-d $\left.d_{6}\right) \delta 2.31(3 \mathrm{H}, \mathrm{s})$, $2.37(3 \mathrm{H}, \mathrm{s}), 7.37,7.79(2 \mathrm{H}, \mathrm{ABq}, J=8 \mathrm{~Hz})$.

Anal Calcd for $\mathrm{C}_{11} \mathrm{H}_{9} \mathrm{O}_{6} \mathrm{Cl}$ : C $48.46, \mathrm{H} 3.33$. Found: $\quad \mathrm{C} 48.63, \mathrm{H} 3.15$.

$N$-(3-Hydroxypropyl)-2,5-dichloro-3,4-dihydroxybenzamide (11b)

To a solution of 2,5-dichloro-3,4-diacetoxybenzoic acid (10b) $(10.0 \mathrm{~g})$ and ethyl chloroformate $(4.8 \mathrm{~g})$ in $\mathrm{CH}_{2} \mathrm{Cl}_{2}(100 \mathrm{ml})$ was added triethylamine $(4.4 \mathrm{~g})$ at $-15 \sim-10^{\circ} \mathrm{C}$. After stirring at the same temperature for 30 minutes, 3-aminopropanol $(4.1 \mathrm{~g})$ in $\mathrm{CH}_{2} \mathrm{Cl}_{2}(15 \mathrm{ml})$ was dropwise added to the reaction mixture below $-10^{\circ} \mathrm{C}$ and the stirring was continued at $-10 \sim-5^{\circ} \mathrm{C}$ for 1 hour. The mixture was acidified by addaing $\mathrm{AcOH}$. After $\mathrm{H}_{2} \mathrm{O}(200 \mathrm{ml})$ was added to the mixture, the organic layer was separated, washed successively with saturated $\mathrm{NaHCO}_{3}$ solution and brine, dried over $\mathrm{MgSO}_{4}$ and evaporated in vacuo. The residue dissolved in $\mathrm{MeOH}(50 \mathrm{ml})$ and triethylamine $(2.0 \mathrm{ml})$ was added to the solution at room temperature. After stirring at the same temperature for 2.5 hours, the reaction mixture was concentrated in vacuo and the residue thus obtained was purified by column chromatography on silica gel with $\mathrm{CHCl}_{3}-\mathrm{MeOH}(10: 1)$ as an eluent to give $\mathbf{1 1 b}(3.3 \mathrm{~g})$ as colorless crystals: MP $170 \sim 171^{\circ} \mathrm{C}$; IR $(\mathrm{KBr}) \mathrm{cm}^{-1} 3330,1635,1575 ;{ }^{1} \mathrm{H}$ NMR (DMSO-d $) \delta 1.65$ (2H, quintet, $J=7 \mathrm{~Hz}), 3.0 \sim 3.7(4 \mathrm{H}, \mathrm{m}), 6.90(1 \mathrm{H}, \mathrm{s}), 8.19(1 \mathrm{H}, \mathrm{t}, J=6 \mathrm{~Hz})$.

Anal Calcd for $\mathrm{C}_{10} \mathrm{H}_{11} \mathrm{NO}_{4} \mathrm{Cl}_{2}$ : C $42.88, \mathrm{H} 3.96, \mathrm{~N} 5.00$.
Found:
C 42.91, H 3.97, N 4.93.

11c: MP $160 \sim 161^{\circ} \mathrm{C}$; IR (KBr) $\mathrm{cm}^{-1} 3510,3310,1575,1555 ;{ }^{1} \mathrm{H}$ NMR (DMSO-d $\left.)_{8}\right) \delta 1.65$ ( $2 \mathrm{H}$, quintet, $J=7 \mathrm{~Hz}), 3.1 \sim 3.7(4 \mathrm{H}, \mathrm{m}), 7.26,7.37(2 \mathrm{H}, \mathrm{ABq}, J=1 \mathrm{~Hz}), 8.20(1 \mathrm{H}, \mathrm{t}, J=6 \mathrm{~Hz})$.

Anal Calcd for $\mathrm{C}_{10} \mathrm{H}_{12} \mathrm{NO}_{4} \mathrm{Cl}$ : C $48.89, \mathrm{H} 4.92, \mathrm{~N} 5.70$. Found: C 48.83, H 4.49, N 5.65.

\section{$N$-(3-Hydroxypropyl)-2-chloro-3,4-dihydroxybenzamide (11d)}

To a suspension of 2-chloro-3,4-diacetoxybenzoic acid (10d) $(2.0 \mathrm{~g})$ in thionyl chloride $(10 \mathrm{ml})$ was added a catalytic amount of dimethylformamide. After stirring at room temperature for 1.5 hours, the mixture was evaporated in vacuo, taken up with $n$-hexane and evaporated again to remove any trace of thionyl chloride. This treatment was repeated twice $(2 \times 50 \mathrm{ml})$. The residue was dissolved in $\mathrm{CH}_{2} \mathrm{Cl}_{2}(20 \mathrm{ml})$ and used in the following reaction.

To a solution of 3-aminopropanol $(0.7 \mathrm{~g})$ and triethylamine $(2.0 \mathrm{~g})$ in $\mathrm{CH}_{2} \mathrm{Cl}_{2}(50 \mathrm{ml})$ was added trimethylsilyl chloride $(2.1 \mathrm{~g})$. Stirring was continued for 1 hour at room temperature and the $\mathrm{CH}_{2} \mathrm{Cl}_{2}$ solution described above was added to the mixture at $0 \sim 5^{\circ} \mathrm{C}$. After stirring at room temperature for 1 hour, the same work-up, deacetylation and purification as that described for $11 \mathrm{~b}$ were carried out to give $11 \mathrm{~d}(1.0 \mathrm{~g})$ as colorless crystals: $\mathrm{MP} 154 \sim 155^{\circ} \mathrm{C}$; IR $(\mathrm{KBr}) \mathrm{cm}^{-1} 3380,1620,1610,1545$; ${ }^{1} \mathrm{H}$ NMR (DMSO- $\left.d_{6}\right) \delta 1.65(2 \mathrm{H}$, quintet, $J=7 \mathrm{~Hz}), 3.0 \sim 3.7(4 \mathrm{H}, \mathrm{m}), 6.71(2 \mathrm{H}, \mathrm{s}), 8.01(1 \mathrm{H}, \mathrm{t}, J=$ $6 \mathrm{~Hz})$.

Anal Calcd for $\mathrm{C}_{10} \mathrm{H}_{12} \mathrm{NO}_{4} \mathrm{Cl}$ : C 48.89, $\mathrm{H} 4.92, \mathrm{~N} 5.70$.

6-[(R)-2-[3-(2,5-Dichloro-3,4-dihydroxybenzoyl)-3-(3-hydroxypropy1)-1 - ureido]-2-phenylacetamido]-penicillanic Acid (1b)

A suspension of $11 \mathrm{~b}(4.0 \mathrm{~g})$, dichlorodimethylsilane $(4.6 \mathrm{~g})$ and triethylamine $(7.2 \mathrm{~g})$ in THF 
$(100 \mathrm{ml})$ was stirred at reflux for 1 hour and trichloromethyl chloroformate $(1.0 \mathrm{ml})$ in THF $(3 \mathrm{ml})$ was added to the mixture at $5 \sim 10^{\circ} \mathrm{C}$. After stirring at room temperature for 4 hours, silylated ABPC which was prepared from ampicillin (ABPC) $(6.5 \mathrm{~g})$, trimethysilyl chloride $(4.7 \mathrm{~g})$ and triethylamine $(4.3 \mathrm{~g})$ in EtOAc $(100 \mathrm{ml})$ was added to the mixture at $0 \sim 5^{\circ} \mathrm{C}$. After stirring at the same temperature for 1 hour, the reaction mixture was poured into ice water. The organic layer was separated and extracted with cold saturated $\mathrm{NaHCO}_{3}$ solution $(200 \mathrm{ml})$. The aqueous layer was adjusted to pH 2.5 with $2 \mathrm{~N} \mathrm{HCl}$ and re-extracted with EtOAc $(200 \mathrm{ml})$. The extract was washed with brine, separated, dried over $\mathrm{MgSO}_{4}$ and evaporated in vacuo. The residue was treated by $n$-hexane to give the crude penicillin $(\mathbf{1 b})(5.7 \mathrm{~g})$ as pale yellow powder. Crude $1 \mathrm{~b}(5.7 \mathrm{~g})$ was dissolved in $5 \% \mathrm{NaHCO}_{3}$ solution $(15 \mathrm{ml})$ and chromatographed over Diaion $\mathrm{HP}-10$ with elution by $\mathrm{H}_{2} \mathrm{O}$ and then $25 \%$ aqueous acetone. The fractions containing the product were combined and adjusted to $\mathrm{pH} 2.5$ with $2 \mathrm{~N} \mathrm{HCl}$ after the addition of EtOAc. The organic layer was separated, dried over $\mathrm{MgSO}_{4}$ and concentrated in vacuo. The residue was triturated with $n$-hexane to give $\mathbf{1 b}(3.1 \mathrm{~g})$ as colorless powder: $\mathrm{IR}(\mathrm{KBr})$ $\mathrm{cm}^{-1} 3700 \sim 2200,1770,1685,1505 ;{ }^{1} \mathrm{H}$ NMR (DMSO- $\left.d_{6}\right) \delta 1.3 \sim 2.0(2 \mathrm{H}, \mathrm{m}), 1.43(3 \mathrm{H}, \mathrm{s}), 1.57(3 \mathrm{H}$, $\mathrm{s}), 3.1 \sim 3.9(4 \mathrm{H}, \mathrm{m}), 4.25(1 \mathrm{H}, \mathrm{s}), 5.3 \sim 5.9(3 \mathrm{H}, \mathrm{m}), 7.18(1 \mathrm{H}, \mathrm{s}), 7.42(5 \mathrm{H}, \mathrm{br} \mathrm{s}), 9.32(1 \mathrm{H}, \mathrm{d}, J=7 \mathrm{~Hz})$, $9.76(1 \mathrm{H}, \mathrm{d}, J=7 \mathrm{~Hz})$.

Penicillins (1c and 1d) were also prepared by the same method as described for $\mathbf{1 b}$.

1c: IR (KBr) cm ${ }^{-1} 3700 \sim 2200,1770,1680,1505 ;{ }^{1} \mathrm{H}$ NMR (DMSO- $\left.d_{6}\right) \delta 1.4 \sim 2.0(2 \mathrm{H}, \mathrm{m}$ ), $1.42(3 \mathrm{H}, \mathrm{s}), 1.56(3 \mathrm{H}, \mathrm{s}), 3.3 \sim 4.0(4 \mathrm{H}, \mathrm{m}), 4.23(1 \mathrm{H}, \mathrm{s}), 5.3 \sim 5.9(3 \mathrm{H}, \mathrm{m}), 7.00(2 \mathrm{H}, \mathrm{br} \mathrm{s}), 7.32(5 \mathrm{H}$, br s), $9.17(2 \mathrm{H}, \mathrm{d}, J=7 \mathrm{~Hz})$.

1d: IR (KBr) cm $\mathrm{cm}^{-1} 3700 \sim 2200,1770,1685,1505 ;{ }^{1} \mathrm{H}$ NMR (DMSO- $\left.d_{6}\right) \delta 1.3 \sim 2.0(2 \mathrm{H}, \mathrm{m}$ ), $1.43(3 \mathrm{H}, \mathrm{s}), 1.57(3 \mathrm{H}, \mathrm{s}), 3.1 \sim 3.9(4 \mathrm{H}, \mathrm{m}), 4.25(1 \mathrm{H}, \mathrm{s}), 5.3 \sim 6.0(3 \mathrm{H}, \mathrm{m}), 6.88(2 \mathrm{H}, \mathrm{br} \mathrm{s}), 7.42(5 \mathrm{H}$, br s), $9.32(1 \mathrm{H}, \mathrm{d}, J=7 \mathrm{~Hz}), 9.93(1 \mathrm{H}, \mathrm{d}, J=7 \mathrm{~Hz})$.

\section{Acknowledgments}

We are grateful to Dr. T. Mori and Dr. S. Matsubara for their encouragement and comments.

\section{References}

1) Oht, N.; B. Aoki, T. Shinozaki, K. Moro, T. Noto, T. Nehashi, H. Okazaki \& I. Matsunaga: Semisynthetic $\beta$-lactam antibiotics. I. Synthesis and antibacterial activity of new ureidopenicillin derivatives having catechol moieties. J. Antibiotics 39: 230 241, 1986

2) Ohi, N.; B. Aoki, K. Moro, T. Kuroki, N. Sugimura, T. Noto, T. Nehashi, M. Matsumoto, H. OkaZaKI \& I. Matsunaga: Semisynthetic $\beta$-lactam antibiotics. II. Effect on antibacterial activity of ureido $N$-substituents in the 6-[(R)-2-[3-(3,4-dihydroxybenzoyl)-1-ureido]-2-phenylacetamido]penicillanic acids. J. Antibiotics 39:242 250, 1986

3) Lightowler, J. E. \& H. J. RYLANCE: Substituted dihydroxybenzoic acids as possible anti-infiammatory agents. J. Pharm. Pharmacol. 15: 633 638, 1963

4) Pettit, R. G. \& D. M. PiataK: Hydrogen bromide-acetic acid demethylation of 2,3-dimethoxy-6-bromobenzoic acid. An example of concomitant bromine migration. J. Org. Chem. 25: 721 725, 1960

5) Karber, G.: Beitrag zur kollektiven Behandlung pharmakologischer Reihen-Versuche. Arch. Exp. Pharm. 162: 480 483, 1931

6) Axelrod, J. \& R. Toмchick: Enzymatic $O$-methylation of epinephrine and other catechols. J. Biol. Chem. 233: 702 705, 1958

7) Komatsu, T.; Y. Kisaki, K. Irie, T. Okuda, N. Akakuri, H. Noguchi, A. Izawa \& M. Konno: On the binding of PC-904 with serum protein or tissue homogenate. Chemotherapy (Tokyo) 26 (Suppl. 2): $154 \sim 158,1978$ 